\title{
Who will look after England's rural disadvantaged now?
}

\section{Commonwealth Journal of Local Governance \\ Issue 16/17: June 2015 \\ http://epress.lib.uts.edu.au/ojs/index.php/cjlg}

\section{Gordon Morris}

University of Exeter

Centre for Rural Policy Research

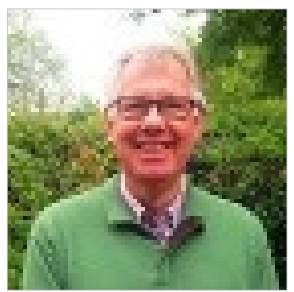

\section{Abstract}

For more than 100 years, non-landed and non-Establishment interests in rural England were represented by a succession of three quasi-independent government bodies (quangos). These were the Development/Rural Development Commissions, the Countryside Agency, and the Commission for Rural Communities (CRC). Their roles embraced, to varying degrees, policy, practice, and advocacy.

In 2013 the British government closed the CRC and absorbed aspects of its responsibilities into the civil service. The implications of this decision for the disadvantaged people and places of rural England are explored. The potential for land-related interest groups and traditional elites to increase their influence as a consequence, is considered.

First, by way of context, the histories of the three quangos and the main interest groups are described. The views of the latter - and others with related interests - were sought (unsuccessfully), together with the opinions of people involved in one or more of the quangos, and, or, the civil service successor unit. These are presented and discussed. Conclusions relating to consequential 'gaps' in independent policy and research are drawn.

The aim is to stimulate discussion about the implications for rural England of closing the CRC, for it is possible that the loss of this small organization may have unexpected long-term consequences. The eventual significance of this decision has yet to be determined.

\section{List of acronyms}

\begin{tabular}{|l|l|l|l|}
\hline ACRE & $\begin{array}{l}\text { Action for Communities in Rural Eng- } \\
\text { land }\end{array}$ & Defra & Department of Food and Rural Affairs \\
\hline AMT & Action for Market Towns & MAFF & $\begin{array}{l}\text { Ministry of Agriculture, Fisheries \& } \\
\text { Food }\end{array}$ \\
\hline CA & Countryside Agency & NFU & National Farmers Union \\
\hline CAll & Countryside Alliance & RCAN & Rural Communities Action Network \\
\hline CLA & Country Land and Business Association & RC & Rural Coalition \\
\hline CoCo & Countryside Commission & RCC & Rural Community Council \\
\hline CoSIRA & $\begin{array}{l}\text { Council for Small Industries in Rural } \\
\text { Areas }\end{array}$ & RCPU & $\begin{array}{l}\text { (Defra's) Rural Communities Policy } \\
\text { Unit }\end{array}$ \\
\hline CPRE & Campaign to Protect Rural England & RDC & Rural Development Commission \\
\hline CRC & Commission for Rural Communities & QUANGO & $\begin{array}{l}\text { Quasi-Autonomous Non- } \\
\text { Governmental Organization }\end{array}$ \\
\hline DC & Development Commission & &
\end{tabular}




\section{Introduction}

In 2013 the British government closed the CRC, ending more than 100 years of support for rural England's people and places. The CRC's predecessors, the Development/Rural Development Commissions and the Countryside Agency, provided practical, academic and policy advice to all governments, irrespective of political colour (Rogers 1999, CA 2000). The CRC was established to,

'meet ... the social and economic needs of persons in rural ... England (especially ... those suffering from social disadvantage and economic under-performance).' (Defra 2005 App 2 p6).

All these organizations were paid for by, but were largely independent of, central government.

The paper reflects the writer's interest in the loss of independent advice and advocacy created by the CRC's closure, and the lack of prior debate, and supporting evidence and analysis. The writer was employed by the RDC and the CA, and worked, on a freelance basis, for the CRC. The paper is written in a personal capacity.

The paper first outlines the history of the CRC, its predecessors. The histories of three farming/landed organizations (National Farmers Union, Country Land and Business Association, and the Countryside Alliance) are also given, as one possible consequence of the CRC's closure is increased influence for lobbying groups such as these. Following this, information gathered from interviews and email exchanges with people involved, or interested, in the changes explored in the paper, are presented, and the implications of the CRC's closure for disadvantaged people and places discussed. Finally, some conclusions are drawn, with the aim of stimulating further debate.

\section{Background}

The CRC was formed, 'to find better ways to identify disadvantaged individuals and communities and to address their situation.' (CRC 2005 p132).

Although it and its predecessors were influenced and directed by landowners and others with, for example, academic or agricultural interests, their responsibilities were broadly drawn; their work more than simply sectoral. Their relative independence from government allowed, indeed enabled and even encouraged, them to challenge, to advocate policy, to research, and to provide advice to the private, voluntary and public sectors, and local - community - groups. In this they differed from landed-interest organizations, such as the NFU, the CLA, and the CAll, and also from preservationist interest groups, for example, the National Trust and the CPRE. Put simply, the QUANGOs represented, at government level, the interests of those outside the spheres of influence of established/Establishment elites and related lobby groups. 
The CRC's role was narrowly defined relative to its predecessors' remits. However, the requirement placed on it, 'to have particular regard to people suffering from social disadvantage and areas suffering economic under-performance' (CRC 2013 p6), enabled long-standing topics of concern, such as housing, transport and services to be addressed.

Today, civil servants in Defra's RCPU are responsible for aspects of the CRC's work (RCPU 2014), and for, 'targeted research into rural issues' (Defra 2013 p6). Their duty is to departmental ministers leading, 'rural policy from within the department.' (Defra 2012),

not, as was the case with the 'arm's-length' CRC, to the people of rural England (Shucksmith 2013).

This change is fundamental. Civil servants do not have the freedom that the CRC's staff had to delve into politically contentious topics, such as disadvantage. For example, one component of disadvantage, poverty, 'tends to be masked by the averages used in area-based statistics, such that poor rural people's needs are not recognised in policy.' (CRC 2008 p160).

The fact that, in 2014, 'more children in working households ... are living in absolute poverty ... than ... in 2009-10.' (Social Mobility and Child Poverty Commission 2014 p.iv) during a period in which relative poverty declined (p.xxv), and with, ' $14 \%$ of households in rural areas ... in fuel poverty ...' (Howard 2015 p12)' only adds to the complicated and contested nature of the topic.

The 2010-15 government was sensitive about poverty; for example, in relation to foodbanks. Chris Mould, chair of the Trussell Trust, a major foodbank charity, said,

'in evidence to the Panel on the Independence of the Voluntary Sector ... that the charity ... had been criticised by the government for raising awareness of the need for foodbanks.' (Civil Society Governance 2014).

Such sensitivity is not surprising: the number of foodbanks in rural England has increased considerably in recent years (Downing and Kennedy 2014; Hutton, Poulter and Robinson 2014; Morris 2014), with usage increasing from 128,697 in $2011-12$ to $1,084,604$ in $2014-15$, a more than eight-fold increase (Trussell Trust 2015). Consequently, the RCPU's civil servants are unlikely to discuss this subject (at least publically), or, indeed, any aspect of rural welfare related to government reforms (Milbourne 2011 p57).

If the work of the CRC and its predecessors demonstrated anything in relation to disadvantage, it is that there is a continuing need to understand, research and monitor, 'the changing forces which act unevenly upon rural people and rural areas.' (Shucksmith, Roberts, Scott, Chapman and Conway 1996 p73). Although Paul Milbourne (2011 p57) asserted that, 'monitoring the impacts of government policy on rural welfare now rests solely with the academic community' the CRC's closure, and the end of its research programme, may have created an academic, as well as a public sector, research 'gap' relating to disadvantage. 
The loss of the CRC may have created other gaps. For example, the CRC had close relationships with councils and voluntary sector organizations, such as RCCs. The RCPU has these connections, but, in view of its status, is not a direct replacement for the CRC. This distinction may explain why, even within parliament, there is concern that,

'With the demise of the [CRC] an independent critical voice has been lost.' (EFRA 2013 p86).

Related to this are worries about the ability of the RCPU, given its relatively small size and single (London) office base, to consult with a sufficiently wide range of external bodies (p86).

Before considering these matters, however, the research method is described.

\section{The research method}

Twenty-three people were asked for their opinions about the CRC's closure. Included were current and ex-officials, politicians, community/economic development practitioners, academics, ex-Board members/Commissioners, a local government officer, a rural business support manager, a regional rural network director, and six parish clerks. All had had some involvement with, or knowledge of, the RDC, CA, CRC, and/or RCPU.

Thirteen people eventually participated. The following declined, had nothing to contribute, or did not reply: one Conservative and one Labour politician (both of whom have held ministerial positions); an academic/ex-Commissioner; a community development specialist and academic; the regional rural network director.

The officials who contributed were colleagues of the writer in the RDC and/or CA. Located mainly in the south-west of England, although with briefs that range, or ranged, beyond the region, they, and the other participants, were approached because of their professional backgrounds, current and/or past employment, and experience.

Five face-to-face interviews were held. The remaining exchanges were conducted via email. The latter were, of necessity, somewhat more 'closed' than the former, which were wider-ranging. In both cases, however, two questions were used to prompt responses:

- What did the CRC do that is not being done now?

- What is government, including the RCPU, unable to do (eg by way of research, to make public), that the CRC was able to do (eg investigate foodbanks, undertake poverty-related work)? 
The NFU, CLA, CAll, CPRE, ACRE, and the Arthur Rank Centre ${ }^{1}$ were also asked to participate. Although initial replies were received from the CAll and ACRE, in the end none of the organizations contributed.

The next section describes the roles of the CRC and its predecessors. Following this, the histories, interests and influence of the NFU, CLA, and CAll are discussed. Finally, the views of the interviewees are presented and discussed, and conclusions drawn.

\section{Rural England's QUANGOs, 1909-2013}

\section{The Development/Rural Development Commissions (1909-1999)}

The $\mathrm{DC}^{2}$ was born of concerns about unemployment in rural areas, and related needs for investment in scientific research, education, and communications and transport infrastructure. These concerns stemmed partly from the impact on the rural economy of the long-running agricultural depression of the late $19^{\text {th }}$ and early $20^{\text {th }}$ centuries, and subsequent calls to address concerns about unemployment by, '... some form of national planning.' (Rogers 1999 pp3-4).

The creation of the DC was informed by three Royal Commissions. Two proposed, respectively, the nationalisation and development of the canal system, and the development of forestry as a means of addressing unemployment and population loss (p4). The third reported on the 1905 Poor Laws and the need for central government involvement in economic and welfare policy (p5).

Although the majority of the (Poor Law) Commissioners argued for the use of public works as a means of reducing unemployment, Beatrice Webb, a founding Fabian ${ }^{3}$, objected (p5). Her objection, presumably, was made on the grounds that those employed on such works would effectively be involved in what would, today, be called workfare. This, in effect a subsidy for the employer, conflicted with the Fabians' support for a minimum wage. The argument is familiar:

'One thing is certain: five million persons insufficiently organized, improperly fed, clothed and housed, can never, by voluntary action, raise the material standard of their life. The one remedy for their lamentable state is larger incomes; the one effective means of obtaining that remedy is a national legal minimum wage.' (TFS 1906 p13).

Voted into being in 1910 with much cross-party support, including that of the then Liberal, Winston Churchill, the DC's work and priorities were influenced by the Royal Commissions. The initial emphasis was on innovation, experimentation, and demonstration covering diverse topics such as bee-

\footnotetext{
1 The Arthur Rank Centre serves the spiritual and practical needs of the rural Christian community through a programme of community and social projects, resourcing and training (http://tinyurl.com/pzuofff).

${ }^{2}$ In 1988 the DC was merged with CoSIRA to become the RDC (Rogers 1999 p136).

${ }^{3}$ The Fabian Society: a British socialist and social reforming organization (http://tinyurl.com/ojm9al5). 
keeping, tobacco cultivation (!), agricultural cooperation, forestry, rural transport, construction and improvement of harbours, and inland navigations (Rogers 1999 p19).

The development of much of the DC's work was ad hoc. Its support eventually extended to the Village Clubs Association, Women's Institutes, the Scottish Rural Women's Institutes' handicraft work, the RCCs, and, via the Rural Industries Bureau, to CoSIRA (Rogers 1999 Ch. 6 and 8). This small, London-based organization eventually became the centre of support for a dispersed, disparate, wide-ranging collection of socially and economically-orientated organizations. These were often county-based, with local committees running local activities. There was much that was 'localist' about this quietly radical state funded conservative organization.

Whatever centralizing intentions and bureaucratic tendencies the London-based Development Commissioners and their staff had were kept in check, or at least challenged, by their partners. For example, the minutes of a meeting of the combined Somerset and Dorset Joint Rural Industries SubCommittee in 1955 in response to a report by the Director of the Rural Industries Board, noted that:

'This report had been fully discussed at a previous meeting ... [and] ... The Chairman said that he felt that the report excluded any opportunity for continuing a long term policy on the part of craftsmen in the region. He also felt that such a policy should not be dictated from London but arise through the aims of the rural areas themselves. ... The General Secretary felt that the proposed 5 year plan was not at all practicable in view of the Conditions of Grant." (S\&D 195522 August).

The chairman of this group was H. Rolf Gardiner, the well-known, if controversial, ruralist (MooreColyer 2001) and supporter of regional development centred on rural estates under the watchful eye of working aristocrats and farming squires (Gardiner 1943 p153). It was usual to have well-connected influential people as members of the DC's (and, later, the RDC's) county committees. In terms of the committee's permanent membership (excluding officials) 'county' landed interests were well represented (which, in the context of this paper, is significant). The one consistent nod towards the wider rural community was the committee secretary, an RCC official. No doubt some in London regarded this as a two-edged sword, given the propensity of people to be loyal both to cause and county. Nevertheless, the DC held the purse strings ${ }^{4}$, for, as also noted in the minutes of August, 1955, the committee members, despite their concerns, accepted the DC's grant conditions (S\&D 1955 22 August).

Although, over time, the priorities and (some) topics addressed changed, the emphasis on research, demonstration, innovation, and specific support, for example, for small businesses and craft training, was to remain constant to the end (eg CoSIRA 1973, RDC 1990, 1994, 1996, 1997, 1997a).

\footnotetext{
${ }^{4}$ As was always to be the case - the purse strings were ultimately held by the Treasury/Whitehall.
} 


\section{The Countryside Agency (1999-2006)}

In 1999 the government closed the RDC as part of its move towards a more integrated and specialised approach to the countryside (DETR/MAFF 2000 p14). Some staff transferred to the newly-formed $\mathrm{RDAs}^{5}$. Others with backgrounds or interests in social and community matters joined $\mathrm{CoCo}^{6}$ staff to form the CA. It was not a single-sector organization. The Board members' interests and expertise ${ }^{7}$ complemented those of the economically-orientated RDC, and mainly environmentally qualified, CoCo staff.

In some respects the CA broadly adopted the RDC's approach. Although it eventually closed the craft training and engineering prototyping centre inherited from the RDC, and moved from county to regional offices, the CA continued to test rural development methods, and to experiment. It maintained an interest in rural crafts, in training, and in continuing the D/RDC's Establishment connections. For example, a collaborative project with, amongst others, the Prince of Wales' organizations, resulted in a report about English country crafts. The Prince wrote the foreword (CA 2004).

The CA, which influenced, and was influenced by, the policy and programme directions given in the contemporaneous rural white paper (DETR/MAFF 2000), was essentially an integrated rural development organization; albeit one which attracted criticism.

For example, Michael Sissons (2001 p174), while not wholly negative, stated that the CA's second annual report (CA 2000a), '... offered a bland and reassuring picture, skirting around most of the difficulties ...' associated with his and his co-contributors' concerns. These included threats: to the landscape from development; to habitats from pesticides and over-exploitation; to farming from free trade, supermarkets and over-regulation; and to rural pursuits and values (Skidelsky 2001 p8).

Although Sissons found the CA's statistical summary useful (p174), Nigel Curry questioned the way in which the CA interpreted and presented economic performance and business data (Curry 2011 pp100-101). There were also questions about whether, 'the Agency suffered from 'initiative-itus': grabbing headlines, raising expectations, but not leaving in place a sustained programme of support.' (Derounian 2006 p5).

Nobody, however, has ever suggested that integrated rural development approaches would be any less controversial than sector specific ones. Rural England is not homogenous (Curry and Moseley 2011

\footnotetext{
5 The emphasis of the work of these eight organizations, together with the London Development Agency, was on economic development: http://tinyurl.com/os2lobu.

${ }^{6} \mathrm{CoCo}$, a quango, was responsible for environmental aspects of the countryside.

7 The Board was eclectic, including academics, clerics, an ex-CLA president, a landowner, an ex-Chief Executive of the CAll, an estate manager, National Park representatives, a retired civil servant, an economist and ex-civil servant, environmentalists, and the General Secretary of the Open Spaces Society.
} 
p7): its people and their circumstances are as varied as the landscapes in which they live. The CA could never satisfy every interested constituency, or constituent.

The demands and expectations placed upon it, coupled with the breadth of its activities, saw the CA grow rapidly (Derounian 2006 p4). Its activities covered social, economic and environmental aspects of rural life; its work supported and informed by extensive research and, in effect, experimentation. Perhaps because of this the CA's demise was attributed to a tendency to rattle, '... too many cages ... [it] ... was seen as too big for its boots ... [i]n particular the monitoring activities ... maybe got up bigger departments' noses. ... In this case 'Goliath' stamped on 'David'.' (Derounian 2006 p9).

Although attention seeking and, more positively, ambition may have contributed to the CA's rise and fall, officially its closure was a consequence of the changes to the machinery of government following the major foot and mouth outbreak of 2001. This involved the closure of MAFF, and its replacement by Defra, which, significantly, incorporated 'Rural Affairs' within both its title and area of responsibility.

Irrespective of this additional responsibility, however, the aftermath of the outbreak quickly saw the needs of agriculture prioritized over other rural people and enterprises (Curry and Moseley 2011 p11): a reassertion of traditional, land-based, priorities.

The CA's short life makes it difficult to assess the impact and effectiveness of its work. The speed of the changes meant that not all programmes were evaluated (CA 2005 p4, Morris 2012), and those that were, were done hastily during the last few months of the organization's existence, when people were applying for jobs, or preparing for redundancy ${ }^{8}$.

Consequently, the opportunity was lost to determine the potential of the agency's integrated rural development work. This was trialled in the Forest of Dean (FoD 2002), and could, if time and politics had permitted, have built on earlier work relating to this rural 'holy grail' (Newby 1988 pp141-145). Although the CA was not established to take an integrated approach, staff tried to address some of the challenges relating to sustainable rural development, and, by extension, to rural governance; in short, '... to tie together the often separate, or parallel, concerns with rural environment, rural society and the rural economy.' (Parker 2011 p21).

However, in 2003 the government asked Christopher (Lord) Haskins, a past-chairman of Northern Foods with a farming background, '... to look at the arrangements for delivering the government's rural policies in England ...' (Defra 2003 p7). Haskins' review was conducted on behalf of Defra, in

\footnotetext{
${ }^{8}$ The writer, a member of the change team, was closely involved in both the evaluation and transfer/redundancy work that preceded the creation of the CRC.
} 
the light of its, '... new leadership role in rural affairs in government' (p171) ${ }^{9}$. His personal preference was for, '... rural delivery in England [to become] much more decentralised than it is, with key decisions being taken at regional and local levels.' (p8).

Haskins believed that policy making should be separated from 'delivery' (ie implementation of policy), and that delivery should be devolved to regional and local bodies such as the RDAs, local authorities, and RCCs (Defra 2003 p44). The weakness in this idea was acknowledged by Haskins, who noted - before disagreeing with the statement - that, 'A criticism of the principle of separation is that it may lead to an even wider misunderstanding between policy development and delivery, whereby policy teams pay little attention to the concerns of delivery.' (p16). The criticism is logical. It is possible, therefore, that the CA's closure, and with it the end of combined policy and delivery work, made it difficult, '... to effectively engage local rural communities in policy and delivery [and] perhaps reflects the difficulties which Defra has in responding to the diversity of rural England.' (Elton 2008 p7).

The government accepted Haskins' recommendation for separation of policy and delivery, but decided to form, '... a much smaller [arm's-length, with little regional presence] organisation, with a new, well focused role providing independent policy advice ... on issues affecting people in rural communities, and analysing and reporting on best practice in the delivery of the Government's rural policies.' (JNNC 2003 p11). The name, Commission for Rural Communities, which was chosen by staff, identifies clearly the intended beneficiaries. Its primary role, to understand, '... what rural disadvantage is and what counter-measures are in different circumstances.' (Burgess 2005 p3), is equally clear. As with the CA, however, the CRC was, as discussed next, to be short-lived.

\section{The Commission for Rural Communities (2006-2013)}

The CRC's focus was on research and the identification and dissemination of good practice relating to disadvantage. However, it was formed at a time when, nationally, the number of public sector employees was being reduced. Consequently, its budget and headcount were always under pressure.

Whereas in 2005-2006 the CA employed 639 full and part-time members of staff (CA 2006 p44), in 2009 the CRC had the equivalent of 64 full-time staff, three fewer than in the previous year (CRC 2009 p45), and that a fall from 84 in 2007 (CRC 2007 p27). By 2011 nearly all its staff had been made redundant. Notwithstanding its size and short life ${ }^{\mathbf{1 0}}$ the CRC produced a lot of research and related literature ${ }^{\mathbf{1 1}}$. It conducted inquiries into hill farming, health, housing, and the roles of rural

\footnotetext{
${ }^{9}$ Prior to the foot and mouth outbreak the CA had answered to the Department for Environment, Transport and the Regions which, jointly with MAFF, had published a Rural White Paper in 2000 (DETR/MAFF 2000).

10 Short lived rural non-departmental government organizations were the norm after 1997, with New Labour and the Conservative-Liberal Democrat coalition governments between them managing to close eight Government Offices of the Regions, the RDC and CoCo in order to to establish - and then close - the CA the RDAs, and the CRC.

${ }^{11}$ A full list of the CRC's - more than 600 - documents can be found here: http://tinyurl.com/p4hxhtu.
} 
councillors, and published case studies about a range of rural issues, including, for example, young people, and migrant workers. It also continued to produce the annual State of the Countryside Reports initiated by the CA in 1999 (CA 1999).

Unsurprisingly, the CRC's documents are easier to find than those of its predecessors. Those of the $\mathrm{CA}$ and the RDC are much harder to track down, although many individual reports can be found by searching the Web. The British Library's main catalogue lists $58 \mathrm{CRC}, 31 \mathrm{CA}$, and $128 \mathrm{RDC}$ documents.

The relative difficulty in tracking down documents from all three organizations is a concern. The documents are repositories of knowledge paid for by the taxpayer. They are all that remain of the 'memories' of organizations, which, for more than 100 years, consecutively cared, and worked, for the people and places of rural England not represented by the land-based, land owning and using membership groups discussed next.

\section{Sector specific and interest groups}

The influential, but partial, NFU, CLA and CAll, together with, for example, the National Trust and the CPRE, have 'insider' connections to politicians and policymakers. Although they could fill some of the gaps left by the closure of the $\mathrm{CRC}^{12}$, their primary responsibility is to represent their members' interests.

\section{The National Farmers Union}

The NFU was formed in 1908, at much the same time as the DC and the CLA. According to its website, the union, formed to represent the interest of farmers during a time of agricultural depression, has grown, '... to become one of the most effective and respected trade associations in Britain.' ${ }^{13}$ It rose from small beginnings to a post-war position of influence, in which it, '... was accorded a key mediating role: representing the interests of the farming community in the implementation of agreed policies.' (Marsden, Murdoch, Lowe, Munton and Flynn 1993 p60).

NFU membership peaked at 210,000 in 1953 (Cox, Lowe and Winter 1991 p30). Standing at 55,000 today, it is still located close, physically and politically, to the heart of central and local government. It is part of the countryside Establishment, an 'insider group' involved in, and influencing, policy making ${ }^{14}$ (Grant 2005 p378, Woods 2005 p137). Its views are promulgated effectively via the

\footnotetext{
12 Although there are other 'insider' groups with land-related interests, such as house builders, forestry bodies and the Ramblers, their influence and roles in relation to disadvantage are either not central to this paper's purpose, or are insufficiently different to warrant specific attention.

13 http://www.nfuonline.com/about-us/history/

14 As an aside, in an illustration of the importance attached the 'the land' relative to the wider rural population, a report by CoSIRA (1983 p2) and the Small Firms Service noted that, in the year 1981/82, the latter employed 225 people (cost $£ 2.56 \mathrm{~m}$ ), CoSIRA employed 301 (cost $£ 4.38 \mathrm{~m}$ ), while ADAS (http://tinyurl.com/oxjvet5), then a government advisory
} 
farming industry's specialist press, such as Farmers' Weekly, and the BBC's Farming Today and Countryfile programmes. In addition, two of the four Defra ministers who served in the 2010-2015 government, Lord de Mauley, a landowner, and George Eustace, a farmer's son, have close farming connections ${ }^{15}$. Owen Patterson, Defra's Secretary of State from 2012 until 2014, is also a farmer's son.

That is not to criticise the NFU - it does its job; as does a related organization, the CLA.

\section{The Country Land and Business Association}

The CLA is also a member of the 'insider' policy community referred to by Michael Woods (2005 p137), and a long-standing influencer of government policy; not least because of the close connections between land owners and the Conservative party (Pierce 2004 p291).

According to its website, 'The CLA is the membership organisation for owners of land, property and business in rural England and Wales. ... Anyone who owns rural land, no matter how much, will benefit from joining the CLA. The CLA is the only organisation dedicated to defending your interests as a landowner ... .' (CLA 2014). In an interview in Country Life magazine (CL 2009) the then president, William Worsley, noted that 50\% of the CLA's 35,000 members owned less than 125 acres. He did not mention that, between them, the members, '... own about 50\% of the rural land in England and Wales.' (CL 2010).

Worsley went on to say that the CLA is, '... a broad church and, philosophically, you support what the CLA stands for, which is fighting for rural Britain.' He continued, 'The CLA's strength is the intellectual quality of its debate. It's got good policy, high-powered members and employs serious scientific brains.' He also - revealingly - noted that, 'after 12 years of Labour, we're still at the top table (in rural politics), with the NFU, and we must remain measured and sensible.' (CL 2010).

Ewen Cameron ${ }^{16}$, a farmer, landowner, and past-President of the CLA, '... personally lobbied [Prime Minister] Mr Blair against wide-ranging 'right to roam' legislation, which would force farmers to allow ramblers on to their land.' (Parker 1999). Consequently, his subsequent appointment as the first chairman of the $\mathrm{CA}$, the organization responsible for the 'right to roam' legislative programme, initially drew some criticism (BBC 1999). Nevertheless, under his chairmanship, legislation was passed, much to the delight of, for example, The Ramblers' Association (Ramblers 2015). In any case, the appointment of a farmer/landowner and Establishment figure to head rural government organizations not primarily, if at all, concerned with agriculture, is essentially the norm.

service for the agriculture sector, employed 5,100 people (cost $£ 65 \mathrm{~m})$. At the time the small firms sector accounted for $25 \%$ of the labour force; the agriculture sector, $2.6 \%$.

$15 \mathrm{http}: / /$ tinyurl.com/klvcdo7

${ }^{16}$ Lord Cameron of Dillington in Somerset. 
For example, the first Chairman of the Development Commission was Lord Richard Cavendish (Rogers 1999 p15), a member of an aristocratic landowning family from the north-west of England. Cavendish was chairman from 1910 until 1946 (p137). Three other of the seven Commissioners had professional connections with land-based industries, thus, intentionally or otherwise, ensuring a majority for these interests ${ }^{17}$. Of Cavendish's six successors (p137), four, Lord Shaftesbury, The Countess of Albermarle, $\mathrm{Mr}-$ now Lord - Vinson, and Lord Shuttleworth (the $5^{\text {th }}$ Baron $^{18}$ ) had, or have, landed/farming interests.

The backgrounds of CLA presidents and chairs of the D/RDC, and CA, are similar: they tend to have strong land-based Establishment connections. For example, the five most recent presidents ${ }^{19}$ all have close personal, professional, and, in some cases, aristocratic and political connections to agricultural and related businesses and interests.

The intentions, therefore, of the CLA and the NFU, in terms of their political aims, are clear. Equally clear, given the sectoral protectionist lobbying roles of these two organizations, is the fact that their aims will not necessarily chime with, support, or be relevant to the concerns of those represented by the CRC.

There is one other organization that broadly occupies the same policy and interest territories: the CAll.

\section{The Countryside Alliance}

The Countryside Alliance (CAll) was formed in 1997, ' ... partly as a response to the newly elected Labour Government's pledge to ban hunting with dogs but also borne [sic] of a need to represent an increasingly marginalised rural minority.' (CAll 2014). The reference to a 'marginalised rural minority' is interesting ${ }^{20}$, in that it could apply to those who hunt with dogs or, alternatively, to the rural disadvantaged. The term is not defined.

The CAll's website highlights its defining countryside demonstrations of 1997, 1998 and 2002. These, '... emphasized a number of issues, including agricultural recession, housing development and the closure of rural services, but the defence of hunting remained the core motivation for both the organizers and the majority of participants ... . References to hunting predominated on the banners

\footnotetext{
${ }^{17}$ In addition to Cavendish, there were six other Commissioners: the social reformer and Fabian, Sydney Webb; Alfred Hall, Director of the Rothamsted Experimental Station; William Haldene, a solicitor and Crown Agent for Scotland; Michael Ennis, a member of the Congested Districts Board of Ireland; Henry Davies, County Land Agent for Carmarthenshire; SaintHill Eardley-Wilmot, a past Inspector-General of Forests to the government of India; and Sir Francis Hopwood, Permanent Under-Secretary for the Colonies (Rogers 1999 p11).

${ }^{18}$ In a good example of institutional and Establishment symmetry, the $2^{\text {nd }}$ Lord Shuttleworth chaired the Royal Commission on canals and inland navigations referred to earlier in this paper (Rogers 1999 p117).

19 David Fursdon, 2005-07; Sir Henry Aubrey-Fletcher, 2007-09; William Worsley, 2009-11; Harry Cotterell, 2011-13; Henry Robinson, 2013-date.

${ }^{20}$ The CAll is an amalgamation of three organizations: the Countryside Business Group, the British Field Sports Society, and the Countryside Movement.
} 
and placards carried by marchers ...' (Woods 2005 p217). Also mentioned is the Alliance's work on rural business and services, and its campaign for improving rural mobile telephone and broadband. This last leads the CAll's 2015 election manifesto (CAll 2014a).

The manifesto also calls for improved food labelling (p3), stresses the importance of wildlife management, '... best achieved by a combination of methods undertaken by farmers, gamekeepers, landowners, naturalists and huntsmen ... ', the repeal of the Hunting Act, and opposition to further restrictions on firearms (p7). Although few of the latter topics are likely to concern the CRC's 'rural disadvantaged', the needs of rural communities and the importance of rural services are not neglected. There are supportive references to the problems of service sparsity and related travel difficulties, the relatively high cost of heating and road fuel, the threat posed to the now privatized Royal Mail's universal service obligation, and the need for affordable housing, together with - interestingly related incentives for landowners to make land available for housing (CAll 2014 pp4-5).

The CAll calls for equality in access to services and facilities to those in urban areas. It is more broadly based in its interests than the NFU and CLA. This is reflected in its governance structure. The Chairman is Kate Hoey, a farmer's daughter and London Labour MP; her deputy is Conservative Peer, Lord Mancroft, a prominent fox hunting chief (Independent 2015). The expertise, interests and connections of many of the officers and members lie more in traditional country pursuits and the Establishment than in the study and understanding of rural disadvantage. Also, they, along with their opposite numbers in the NFU and CLA, have access to political and policy making worlds denied to the average rural dweller. They are - quietly - influential.

\section{The Establishment's Quiet Influence}

Today, the programmes introduced in the Rural White Paper of 2000 (DETR/MAFF 2000) are largely history. Local government and voluntary sector budgets have been cut, and funding for communityrelated research is hard to find. With the CRC abolished, and policy development a civil service function, the landed, farming and county 'insider' organizations, institutions and individuals, together with the preservationist groups, may, without the CRC's countervailing voice, be assumed by some to speak for - all of - rural England. These changes are significant; they smack of High Toryism, a reassertion of traditional landed influence ${ }^{21}$.

The CAll, NFU and CLA are not disinterested. They exist to serve their members, some of whom may be, '... as militant as coalminers.' when fighting for their interests (Rose, Saunders, Newby and Bell 1979 p18). Some serve as elected members of local authorities (Pierce 2004 p 291), and are often holders of honorary posts, such as Lord Lieutenant and High Sheriff. As appointees and local

\footnotetext{
21 The sociological implications of these changes in terms of power relationships and the exercise of influence are ripe for re-investigation, and would complement the work of, for example, Newby, Bell, Rose and Saunders (1978), Woods (1997), Pierce (2004), and Sturzakar and Shucksmith (2011).
} 
representatives of the Crown ${ }^{22}$ the latter are Establishment figures. Largely 'invisible in plain sight' they have connections to centres of power, and the potential to exert 'quiet' influence within local and central government.

Indeed, some of the 'County' landed and farming families have held these appointments so often over the centuries that they are a (semi)-permanent presence. Well connected, their influence radiates out from county to Westminster. Their interests, concerns and priorities will, as Rose et al. noted (1979 p11), most likely reflect, '... their values, their beliefs and their ideologies, and thus indirectly further their interests to the detriment of less powerful and less prosperous groups.' Not surprisingly, they speak mainly for their own.

The RCPU, however, has a wider constituency to consult with, and (attempt to) satisfy, as discussed below.

\section{The RCPU - Rural Communities Policy Unit (Defra)}

Concerns have been expressed about the RCPU's ability to consult only the 'usual suspects' (EFRA 2013 p84). The suspects are, however, numerous, and are themselves often representative organizations with networks of their own.

For example, in addition to the organizations noted in the previous section, the suspects include ACRE's RCAN (the RCCs' representative body), the Rural Services Network, RC, Rural and Farming Networks, Local Enterprise Partnerships, and the European Union LEADER programmes' Local Action Groups. As these are representative membership bodies it can be argued that the views of most interested organizations are consulted, if indirectly. For example, the Plunkett Foundation, which stated that the RCPU liaises directly with too few organizations (EFRA 2013 p84) is a member of the RC, as are, along with others, the NFU, CLA, ACRE, and local government organizations.

Other organizations, such as the NHS, with which the CRC worked (CRC 2008a), also have views, policies, responsibilities, experience and concerns relating, for example, to rural disadvantage. Their opinions are relevant as recent research suggests downward social mobility (Bukodi, Goldthorpe, Waller and Kuha 2014 p21) and hunger appear to be increasing (APPG 2014).

There is a concern that the RCPU - a relatively small unit compared with the $\mathrm{CRC}^{\mathbf{2 3}}$ - is not in a position to address specifically, and as a priority, the needs of the rural disadvantaged, or, as of right, to conduct related research, and to advocate. According to Defra (2012), the RCPU focusses, '... on Ministers' stated rural priorities - housing, broadband, services, transport and fuel ... [and] ...

\footnotetext{
${ }^{22}$ Lord Lieutenants and High Sheriffs are technically crown appointments, and so are deemed to be non-political. The former are appointed by the Queen on the advice of the Prime Minister (http://tinyurl.com/cpk9gkb); the latter are essentially judicial nominations (http://tinyurl.com/newgcxp). Both posts are unpaid.

${ }^{23}$ Information and views about the RCPU's work are to be found here: http://tinyurl.com/mapdh8f
} 
programmes designed to drive rural economic growth ... elements of the [Rural Development Programme for England $\left.{ }^{24}\right]$, and ... measures announced in the Rural Economic Growth Review. ${ }^{25}$. These topics and programmes are relevant in terms of disadvantage, but the relevance is implicit, rather than, as in the CRC's case, explicit, and of primary importance.

The challenge facing the RCPU, therefore, is considerable. Consequently, it is understandable that 'rural proofing' ${ }^{26}$ is emphasized as an, '... area of our policy that is increasingly important across government.' (Defra 2014 p4).

Ministers - politicians - and not independent individuals appointed for their knowledge and experience are now responsible for policy. This is a significant change, which, when coupled with the - consequent? - paucity of research relating to disadvantage, suggest that policy 'gaps' may now consequently? - exist in topic areas once addressed by the CRC. This is discussed in the next section.

\section{Consequences of the CRC's Closure - Participants' Views}

Participants noted 'post-CRC' gaps in independence, information, research and, in relation to town/parish councils, communication.

An ex-senior official, who had worked for the RDC, CA and CRC, said, 'Its strength was to think independently ${ }^{27}$ and advocate independently from an outside perspective.' Although acknowledging that others could have done its work, its, '... unique feature was its freedom ... from government and the civil service.' An ex-CRC Commissioner noted that although the CRC was unable to continue with some of the more practical, action-research work done by the CA, such as the Land Management and Market Towns initiatives, its clearly defined role, and its day-to-day focus on social justice, rural deprivation and inclusion, was distinctive and valuable; as was its strong emphasis on influencing policy across government departments. This last point was reinforced by an academic and an exofficial, both of whom, contrary to Lord Haskins' view, attached importance to the - now lost - link between the development of policy and its implementation.

In terms of work not being done, a research specialist in housing and community development mentioned the annual State of the Countryside Reports, related data, and research reports. Another ex-Commissioner noted the value, in terms of independence, of the CRC's work on the rural economy

\footnotetext{
${ }^{24}$ Information about the LEADER RDPE can be found here: http://tinyurl.com/lekcqct.

${ }^{25}$ Available at: http://tinyurl.com/lw9une5

${ }^{26}$ The process used to ensure that government policies take into account the needs of rural people, business and communities in England. More information can be found here: http://tinyurl.com/qzvdey7.

${ }^{27}$ Several references to the CRC's relative independence from government were made, unprompted, and with varying degrees of emphasis, by participants who had worked for the CRC. Although their views could be biased, two of those who made the point had worked for both the CRC and RCPU, two others had worked for neither, and the CRC's weaknesses as well as strengths were acknowledged.
} 
and 'digital divide'. Given that it was, '... proactive and not reactive ...', it was able, '... to persuade/influence Ministers to take issues seriously - ie the rural poor.'

The officials with CRC and civil service experience noted the CRC's freedom to consider topics which were not government priorities or necessarily popular with other rural stakeholders ${ }^{28}$. Its focus on matters relating to poverty helped ensure clarity of purpose. However, although the CRC gathered a lot of evidence and, '... had a co-ordinated approach to influencing government across a wide range of issues ...', more could have been done to inform policy development. The point was made that, although the RCPU is, '... able to do a lot of the types of research ... done in the past.', there are fewer opportunities to conduct CRC-style thematic studies; officials, ' ... offer options and advice, but the Minster makes the final decision about priorities.'

In terms of the CRC's influence on government, two views illustrate the tensions that can occur when a state funded organization produces evidence or provides advice that runs counter to government priorities and policy direction. An ex-Commissioner stressed the CRC's independence, but noted the need, '... to be sensible ... [not] ... aggressively, unpleasantly critical of the government that's paying your bills ... we could be pretty robust in what we said ... some government ministers ... found that easier to cope with than others ... . We didn't hold back, but you've got to be constructive.' The difficulty in achieving the right balance between welcome and unwelcome advice is summed up by one official:

The problem was that often [the CRC's] voice was at discord with what government wanted to hear and wasn't always couched in the best tone. ... The CRC was good at identifying insightful evidence and data, but did not link this all to policy. ... staff worked hard to find evidence and highlight an issue but didn't work to follow this up with appropriate policy solutions. ... the CRC was just starting to adapt to this approach (evidence to support policy cycle way or [sic] working), ... as it was disbanded.

An ex-RCC worker, now a social policy lecturer, found the CRC's reports and case studies, especially those relating to young people and housing, accessible. They were free of jargon, and gave examples of good practice. The interviewee wondered if a post-CRC 'information gap' now exists.

The ex-senior official noted that the CRC was under continual pressure to reduce the number of staff, and to spend less money. This, '... hobbled it from the beginning', suggesting that the CRC's creation was, '... probably more a political decision than a rational policy decision.' Its effective replacement by the RCPU, however, has resulted in a loss of research capacity, in that Defra's, '... research programme is very narrowly focussed ... on their policy objectives ... we're not getting that more enquiring primary research that the CRC, I think, was very good at.'

\footnotetext{
${ }^{28}$ However, the point was made that the CRC's independence was relative, as its corporate plans had to be 'signed-off' - ie approved - by government (see footnote 4).
} 
Consequently, the interviewee added, 'The land-based organizations [eg NFU, CLA, CAll) have more clout than they had before.', before noting, 'I don't think that moving the work into government is all bad. There are things that are lost, and possibly one or two things that have worked better. Having civil servants working inside the machine has got perhaps more traction with other Whitehall departments ... .' An official supported this view, saying that, although the RCPU lacks the CRC's independence, its place in government means that it can respond quickly to demands, and is better placed to influence wider government policy.

Where poverty is concerned, an academic stated, 'The key for me is that 1 in 5 rural households in/at margins of poverty ... since the late 1970 s ... an indictment on every successive government since that time.' The ex-senior official thought that, although the RCPU could investigate topics related to poverty, it is unlikely to do so. This is because the RCPU is, '... more reactive to policy changes ... its work programme geared to policy changes that are happening ... rather than standing back and saying, 'What are the big issues out there?' ... Also so much of a civil servant's time is spent on dayto-day ministerial matters ... .' (a view supported by a civil service contributor).

The same concern was also expressed by an ex-Commissioner, who said, 'What's missing is any real sense of independent scrutiny ... and a lack of public visibility relating to its work. [The RCPU is] ... very, very invisible ... you talk to people in the Local Government Association or any of the nongovernment organizations ... they're not thinking of the [RCPU]. It's not really at the forefront ... it's doing some good stuff ... on rural proofing, because they've got good people there, but it's, it's, it's, just beneath the radar. ... It lacks ... critical edge ... independent voice ... resource.'

The perceived lack of independence and visibility is perhaps inevitable, because, as a civil servant observed:

The RCPU has to work to Government (Ministerial) priorities ... For example, Rural Services, poverty etc were not cited as one of [the Secretary of State's] priorities, so much of our work was reconditioned to reflect rural economy. ... As (sic) the expense of many other issues that need to be addressed in rural areas, including poverty.'

The successful aspect of the RCPU is that it can engage at the top table with other government departments - to an extent. Over the last three years ... it has taken giant leaps forward.

The Achilles heel of the RCPU is twofold. It is part of government and ultimately it is not able to be a critical friend in the truest sense. The second weakness is that it is not fleet of foot and thus is unable to respond to issues quickly if they aren't a ministerial priority.

These views capture the strengths and weaknesses of having a unit within government. It is part of the machine, its staff trusted by colleagues in other departments, its professional ethos unquestioned, but its freedom to act and communicate outside government and the civil service limited by remit and duty. Not surprisingly, the CRC's position was considered to be relatively free. It was, according to a 
civil servant, '... highly responsive and unrestricted by any political priorities, meaning that it could dig deep to uncover the facts and present the truth even if this embarrassed government - this was the very essence of what it was good at - but ultimately its downfall.'

Whether the potential to embarrass the government of the day was the reason for its downfall is open to question. Along with many other arm's-length bodies it was a casualty of the present government's 'bonfire of the quangos' (Institute for Government 2012). This, the latest bonfire of many, concentrated on non-departmental public bodies, such as the CRC, rather than, for example, health authorities (Flinders, Dommett and Tonkiss 2014 p20). As, according to government figures, some 280 quangos have been abolished or merged since 2010 (UK Government 2014), it is possible that the CRC was simply one of many chosen, possibly without much thought for the consequences, for summary incineration.

Nevertheless, the opinions expressed above about relative freedom, and concerns relating to rural deprivation and poverty noted by the House of Commons' environment, food and rural affairs committee (EFRA 2013 pp100), suggest that the closure of the CRC, and with it, the loss of, '... an independent critical voice ...' (p86), has implications for rural England (and, perhaps, for all 'critical friends' who are seen to be overly critical by, and of, their paymasters). Similarly, the Government's belief that these topics are best dealt with via rural proofing (EFRA 2013a p28) and external monitoring and reporting (p29 $\left.{ }^{29}\right)$, makes clear the RCPU's distinct status within, and of, government.

The point above about the loss of research effort and capacity is reflected in the comments made by the business support manager, who, although recognizing the CRC's closeness to government, viewed the change with concern, stating:

The demise of the CRC has left ... villages and towns without a place to turn to for authoritative research, advice and guidance. It has also deprived them of the ability to ... contribute to a collective voice on issues of concern. Despite being clearly linked to government it was respected for its independence.

The reference to the value of the CRC's work to the parish council level is interesting in that information gathered from parish clerks suggests that the value may be more assumed than actual. As part of this research a parish clerk consulted five colleagues who, between them, cover fifteen parish councils. Most of them have been clerking for between ten and twenty years, and yet two had not heard of the CRC, and had to search the Web for information. In a similar vein, a rural District Council officer with more than twenty years' experience in community - including town partnership development work, felt, due mainly to the day-to-day pressures of work, detached from changes at the

\footnotetext{
29 This refers to Defra's annual report on investment in the ACRE network (ACRE 2013). The report mentions poverty only in the context of fuel poverty. Disadvantage is mentioned once, in connection with grants made to RCCs. Deprivation is not mentioned.
} 
national level, and was unaware, for example, that AMT, an organization that had, since the late 1990s worked with, and for, town partnerships, had closed ${ }^{30}$.

The clerks' and District Council officer's lack of awareness suggests that there may be a communications gap between central and local government that precedes the establishment of the RCPU. This possibility is consistent with a 2014 survey of town clerks that found an overall lack of familiarity with the CA-led programmes contained in the rural white paper of 2000 (Morris 2014). National organizations cannot, therefore, be complacent when it comes to communicating with local government officers, especially town/parish clerks who are often part-time and, consequently, under time and work pressures (p67).

To an extent this can be seen from the clerks' collective, and somewhat dismissive, response to the second question (namely, what is government unable to do that the CRC was able to do): 'There was nothing that could be found that the CRC did [relating] to Parish and Town Councils that isn't being done now.' However, no examples were given.

The business support manager answered this question slightly differently, stating that, 'From a national point of view there is nothing that government can't do to compensate for the loss [of the CRC].', before adding:

The problem is that they [the government] have no will to do it. They have dramatically cut back on the type of research that reveals the real needs of rural communities and strangled the independent voice that at times was able to contribute to and or seriously challenge government thinking, policy and practice. ... DEFRA works with 35 agencies and public bodies, but not one of them focusses on rural deprivation ....'

Finally, in addition to the work of the CRC and the RCPU, the role of the Rural Advocate (RA) was mentioned. This position, initially located within the $\mathrm{CA}$, and subsequently the $\mathrm{CRC}$, gave the holder access to the highest levels of government, including the Prime Minister (CRC 2008b). The RA was also responsible for informing, '... government about the reality of the diverse and changing needs of rural communities, businesses and individuals.' (Wiredgov 2008). The role was abolished, along with the CRC, despite pleas from, 'Lord Cameron of Dillington, who was appointed [RA] by Tony Blair in 2000, [and who] 'begged' ministers to rethink their plans, warning of the 'still unrecognised issues of rural deprivation, which continue to come very low on every Government's priorities'.' (Independent 2011). This, coupled with the decision not to update the Rural Statement (Defra 2012a) after many decades of regular reporting is indicative of the extent to which the closure of the CRC and the formation of the RCPU has changed the former consensual approach to rural development in England.

To judge from the above, gaps do appear to have opened in relation to policy, research, and independence from government. After more than 100 years, this is change indeed.

\footnotetext{
${ }^{30}$ AMT appointed a liquidator in 2014. The writer was, until 2013, a Trustee and Director of AMT.
} 


\section{Conclusion}

This paper set out to consider the implications of the closure of the CRC, and its replacement (in effect) by the RCPU, for rural England's disadvantaged people and places. The main concerns identified are the:

- loss of independence associated with the replacement of an arm's-length organization by a civil service unit;

- lack of a coherent research programme relating to disadvantage;

- potential for policy influence to be skewed in favour of membership and lobbying groups and professional and landed elites;

- possible lack of effective communications between central government bodies and lower tier local authorities.

Almost thirty years ago the Church of England's discussion about rural disadvantage concluded that:

If people are really able to see that poverty does exist, even in posh rural areas, they are more likely to do something about it locally as well as demanding changes in national policies and provisions. ... We and the politicians need to feel uncomfortable. (emphases as in original) (Lewis and Talbot-Ponsonby 1987 p200).

Today, the church is making much the same plea in relation to a much more obvious indicator of poverty, hunger (APPG 2014 p43). To judge from the growth in the number of foodbanks ${ }^{31}$ and volunteer helpers - 30,000 in 2013/14 (Trussell Trust 2014) - it seems that although people have heeded the 1987 call, the same cannot be said of all politicians ${ }^{32}$, or of government. As one contributor to this paper noted, the level of poverty in rural England remains a concern, and perennial problems relating to access to jobs, housing and transport continue.

In the late 1970s a report by the Standing Conference of RCCs noted, 'The combined effects of the loss of services on individual communities can ... be enormous. In aggregate terms too the many threatened closures to schools, garages, post offices and shops etc. represents a massive change to the scale and form of rural life in England.' (Clark and Smith 1978 p49). Similar points have been made since by a variety of organizations about the many facets of disadvantage and the effects on different constituencies (Smith 1992, Hale 1996, CA 2002, Age UK 2013), with perhaps the CRC's, now nearly decade old, research into older people being the most recent detailed study (CRC 2006).

\footnotetext{
31 An example of usage: between November 2013 and November 2014 a foodbank in a small country town in the south of England distributed 16.5 tonnes of food. In all, in the twelve month period December 2013 to November 2014, 92 couples, 114 families, 270 single people, and 86 single parents were helped. In 2013/14 the reasons given for use were (in rank order): low income, benefit delays, benefit changes, and debt (Mac 2014).

${ }^{32}$ Quotes relating to foodbank use by members of the 2010-15 Coalition government include: 'I think one of the reasons that there has been increased use ... is because people have been made aware of the ... service through local jobcentres.'; 'I think it is a positive thing for people to use food banks and I think if they need it, local authorities sometimes refer to food banks now because they run the social funds and instead of actually just paying money out some of them refer across.'; 'It is difficult to know which came first - supply or demand... if you put more food banks in, that is the supply. Clearly food from a food bank is by definition a free good and there's almost infinite demand.'
} 
The perennial nature of poverty and its close semantic relations, disadvantage, social exclusion and deprivation, suggests that they are intractable problems. They may be so, but for politicians to turn their backs on attempting to understand and solve them is no answer. Indeed, it is arguably a dereliction of duty; a failure to work for the common good. The change from independent advice to Minister-led policy is short sighted. Ministers and governments come and go, but the problems are long-term (which perhaps explains why, until 2013, a consensual approach was essentially the norm).

The debate, however, is not primarily about the pros and cons of arm's-length versus civil service bodies. It is about what needs to be done for disadvantaged people and places, and how best to develop and implement policy responses.

In the late 1980s, in similarly straitened times, the National Council for Voluntary Organisations helped create RV, an umbrella body for groups such as farming organizations, RCCs, the National Federation of Women's Institutes, CPRE, and the National Association of Local Councils (Rogers 1999 p102). A politically active lobby group (p103), RV's equivalent today is the RC (ACRE 2012 p1), established by the CRC in 2008 (RC 2010).

The RC's thirteen members ${ }^{33}$ have recently produced a report which, '... sets out [its] headline priorities for the next government.' (RC 2014 p2). These - seemingly inevitably - centre on matters relating to the economy, housing, and physical and social health. Interestingly, there is only a passing reference to rural services, and the words, disadvantage, poverty, and deprivation, do not appear. This is surprising given that a recent government-sponsored literature review lists both the - well known reasons why the cost of providing, for example, public transport services in rural areas is relatively high (Ranasinghe 2014 p13), and the main factors affecting rural disadvantage (p17). Indeed, even the government's rural statistical survey (Defra 2014a) notes, 'Proportionally more households in rural areas are in fuel poverty than the national average.' (p102), and that, '...many thousands of individuals living in rural areas are in households below average income.' (p85).

The failure of the RC's report to mention, let alone emphasize, these major rural concerns could be a reflection of the priorities of the majority of its membership. It may, however, indicate nervousness in connection with these topics - an implicit recognition that the CRC's closure signalled the end of an era in which rural policy encouraged research and practice designed to address, and overcome, rural disadvantage. The omissions are disappointing, not least because the RC's predecessor, RV, according to ACRE (2012), helped persuade a Conservative government to publish the first ever rural white paper (DoE/MAFF 1995 p3).

\footnotetext{
${ }^{33}$ ACRE, Arthur Rank Centre, CLA, CPRE, National Association of Local Councils, NFU, National Housing Federation, Plunkett Foundation, People and Places, Royal Institute of Chartered Surveyors, Royal Town Planning Institute, Rural Services Network, Town and Country Planning Association.
} 
The white paper not only drew attention to disadvantage (DoE/MAFF 1995 Ch.3), but also undoubtedly influenced the priorities of the second white paper (DETR/MAFF 2000) published by a Labour government. This paper also recognized the need to address disadvantage by, for example, providing '... support for deprived rural areas ... better rural services which combat poverty and social exclusion ... [and] ... support to develop ... market towns ... as service centres.' (p12).

The practical and academic work arising from the two white papers is receding now in terms of history and institutional memory (Morris 2014). It seems that government is uninterested in rural development as understood by the D/RDC, CA and CRC. For example, there were doubts about Defra's willingness, after approximately 90 years, to support ACRE financially (ACRE 2015 p2) 34 $^{34}$ This seeming reluctance by government provokes the question: who will ensure today's wider 'rural voice' will be heard by politicians and policy makers? The responsibility cannot lie solely with the RC. Neither can it - and nor should it - lie with lobby groups or Establishment membership organizations.

There are, as this paper has described, rural organizations aplenty, but they all have their own priorities and vested interests, and few, if any, have the duty, remit or resources to make rural disadvantage their raison d'ẹtre, as was the case with the CRC. In the five years since the 'Big Society' self-help approach was announced (Conservative Party 2010) there is little to suggest that voluntary effort alone can do the work once done by the $\mathrm{CRC}$, its predecessors, and researchers. In fact, the limits of volunteerism were presciently critiqued in the 1980s: '... the attraction of self-help policies to a central government administration ... committed to a programme of public expenditure cuts virtually guarantees their continuation and even their increasing importance.' (McLauglin 1987 p364). Although Rogers (1987 p359) questioned aspects of McLaughlin's reasoning, he understood the need for public sector involvement in tackling rural disadvantage:

'it must be recognised that the voluntary approach to rural community development is but one means to an end and one which inevitably has its limitations. It is predominantly consensual rather than conflictual in its approach and has a long standing tendency to accept existing structures within rural society rather than oppose them. It must be seen, therefore, to be matched by a balancing statutory foundation for rural social policy which is able to recognise deep-seated structural weaknesses in the economy and society of rural areas and to set the framework of rural policy (within which the voluntary sector must operate) accordingly.' (Rogers 1987 p360).

Ultimately, only the state can ensure fairness.

The decision to close the CRC appears to have been primarily driven by the government's desire to reduce the number of quangos, rather than by an objective analysis of need and benefits. It is a

\footnotetext{
34 The government's decision to continue to support ACRE came shortly after an online petition in support of ACRE gathered more than 13,000 signatures, at an eventual rate of more than 1,000 a day (http://tinyurl.com/phkluar).
} 
decision that flies in the face of more than 100 years' experience and broad political consensus. Also, it lacks logic. There is evidence that poverty remains dynamic, and is, for some people, persistent and entrenched (Hills 2015 pp124-132), suggesting a need for continued policy responses and associated research ${ }^{35}$.

It may be that politicians will come to regret closing the CRC (Hetherington 2013). For, with each year that passes, the information, recorded experiences, research findings, case studies, and exemplars of good practice produced by the CRC and its predecessors, become more dated and difficult to find. When, inevitably, it becomes necessary to revisit these topics, to fill the gaps identified and discussed above, the body of work of these organizations will have much to offer tomorrow's policymakers and practitioners ... if they can find it.

\section{Acknowledgements}

I am particularly grateful to the people who shared their views about the changes explored in the paper. Their names must remain confidential. However, they know who they are, and know I am grateful. Thanks also to Claire Nichols. Her comments on the early drafts helped enormously. Any errors or omissions are, of course, entirely my responsibility.

\section{References}

ACRE. 2012. Celebrating twenty-five years of rural community action. Available at: $<$ http://tinyurl.com/ppb3tva $>$. Accessed: 03 January 2015. Action with Communities in Rural England, Cirencester, Glos. UK.

ACRE. 2013. Making a difference in rural communities throughout England.

2012-13 Annual report on Defra's investment in the ACRE Network. Available at: <http://tinyurl.com/mjqngee>. Accessed: 09 December 2014.

ACRE. 2015. The ACRE Network - the case for transitional funding.

Age UK. 2013. Later life in rural England. Available at: <http://tinyurl.com/qemu3ng>. Accessed: 04 January 2015. pp33.

APPG. 2014. Feeding Britain. A strategy for zero hunger in England, Wales, Scotland and Northern Ireland. The report of the All-Party Parliamentary Inquiry into Hunger in the United Kingdom. ISBN: 978-1899783-48-9. The Children's Society, London. Available at: <http://tinyurl.com/olbg5xp>. Accessed: 05 May 2015. pp56.

BBC. 1999. Anger as landowner heads Countryside Agency. Available at: <http://tinyurl.com/qzdc5xw>. Accessed: 03 September 2014.

\footnotetext{
35 Other organizations, eg, Joseph Rowntree Foundation (www.jrf.org.uk), the Institute for Public Policy Research (http://www.ippr.org/) and the Centre for Social Justice (http://www.centreforsocialjustice.org.uk/) are also interested in poverty/disadvantage, and related matters, but their interests are not specifically rural, and they do not occupy the CRC's governmental/policy/advisory niche.
} 
Bukodi, E., Goldthorpe, J. H., Waller, L. and Kuha, J. 2014. The mobility problem in Britain: new findings from the analysis of birth cohort data. The British Journal of Sociology. doi: http://dx.doi.org/10.1111/1468-4446.12096

Burgess, S. 2005. The State of the Countryside 2005. Commission for Rural Communities, London.

CA. 1999. The State of the Countryside 1999. ISBN 086170603 X. The Countryside Agency, Cheltenham, UK.

CA. 2000. Tomorrow's Countryside - 2020 Vision. The future of the countryside and the Countryside Agency's role in shaping it. The Countryside Agency, Cheltenham. pp19.

CA. 2000a. The State of the Countryside 2000. ISBN 086170638 2. The Countryside Agency, Cheltenham, UK. pp68.

CA. 2002. Rural Services in 2000. The South East and London. CAX92. The Countryside Agency, Cheltenham, UK. pp30.

CA. 2004. Crafts in the English Countryside: Towards a Future. CA 200. ISBN 0-86170-689-7. The Countryside Agency, Wetherby, West Yorkshire, UK. pp324.

CA. 2005. Countryside Agency Annual Report and Accounts, 2004/05. HC374. The Stationery Office, London. Available at: <http://tinyurl.com/kuphdgy>. Accessed: 03 October 2014.

CA. 2006. Countryside Agency Annual Report and Accounts 2005/06. The Stationery Office, Norwich, UK. Available at:<http://tinyurl.com/nkbntjt $>$. Accessed: 15 September 2014.

CAll. 2014. Countryside Alliance. About the Countryside Alliance. Available at: <http://tinyurl.com/mlq8kg9>. Accessed: 26 September 2014.

CAll. 2014a. Countryside Alliance. Countryside Alliance - General Election manifesto 2015. Available at: $<$ http://tinyurl.com/obs96cx>. Accessed: 26 September 2014.

Civil Society Governance. 2014. Trussell Trust told 'the government might try to shut you down'. Available at: <http://tinyurl.com/q4kugsm>. Accessed: 17 October 2014.

CL. 2009. Country Life. Country Life Interview: William Worsley. Available at: <http://tinyurl.com/n2u8rn9>. Accessed: 25 September 2014.

CL. 2010. Country Life. Who really owns Britain? Available at: <http://tinyurl.com/m9cxng8>. Accessed: 20 October 2014.

CLA. 2014. Country Landowners and Business Association Home Page. Available at: $<$ http://tinyurl.com/lwzjhfw>. Accessed: 25 September 2014.

Clark, D., and Smith, M. 1978. The Decline of Rural Services. The Standing Conference of Rural Community Councils, Bedford Square, London.

CoSIRA. 1973. Select list of books and information sources on trades, crafts, and small industries in rural areas. Publication number 17. Council for Small Industries in Rural Areas, Wimbledon, London. pp80.

Conservative Party. 2010. Big Society, not Big Government - building a big society. Available at: $<$ http://tinyurl.com/q4jh6br>. Accessed: 04 May 2015. pp16.

CoSIRA. 1983. Report on the Experiment in Joint Management of the Advisory Services of the Small Firms Service and the Council for Small Industries in Rural Areas From 01 October 1981 to 30 September 1982. British Library Official Publications GPB2351. CoSIRA, Salisbury, UK.

Cox, G., Lowe, P., and Winter, M. 1991. The Origins and Early Development of the National Farmers' Union. Agricultural History Review, 39. I, pp30-47.

CRC. 2005. State of the countryside 2005. Commission for Rural Communities, Cheltenham, UK. 
CRC. 2006. Rural Disadvantage. Quality of life and disadvantage amongst older people - a pilot study. Commission for Rural Communities, London. pp88.

CRC. 2007. Commission for Rural Communities Annual Report and Accounts 2006/07. The Stationery Office, Norwich, UK. Available at:<http://tinyurl.com/qeet9ak>. Accessed: 15 September 2014.

CRC. 2008. State of the countryside 2008. Commission for Rural Communities, Cheltenham, UK.

CRC. 2008a. NHS Next Stage Review. Rural consultation events. The views of patients the public and health professionals. (Our NHS, Our Future: a rural response). Commission for Rural Communities, Cheltenham, Gloucestershire, UK. pp106.

CRC. 2008b. England's rural areas: steps to release their economic potential. Advice from the Rural Advocate to the Prime Minister. Available at: <http://tinyurl.com/mym5kez>. Accessed: 30 December 2014.

CRC. 2009. Commission for Rural Communities - Annual Report and Accounts 2008-09. Available at: $<$ http://tinyurl.com/kvhok64>. Accessed: 15 September 2014.

CRC. 2013. Annual Report and Accounts, 2012-2013. ISBN: 9780102982565. The Stationery Office, Norwich, UK.

Curry, N. 2011. The Rural Economy. In: Curry, N., and Moseley, M., A Quarter Century of Change in Rural Britain and Europe. Reflections to mark 25 years of the Countryside and Community Research Institute. ISBN 1-86174-211-8. The Countryside \& Community Press, CCRI, Gloucester, UK. pp91-102.

Curry, N., and Moseley, M. 2011. A Quarter Century of Change in Rural Britain and Europe. Reflections to mark 25 years of the Countryside and Community Research Institute. ISBN 1-86174-211-8. The Countryside \& Community Press, CCRI, Gloucester, UK. pp91-102.

Defra. 2003. Rural Delivery Review. A Report on the Delivery of Government Policies in Rural England. Product code PB8856. Department of Environment, Food and Rural Affairs, London.

Defra. 2005. Draft Natural Environment and Rural Communities Bill. Cm6460. ISBN 0-10-164602-X. The Stationery Office, PO Box 29, Norwich, UK.

Defra. 2012. Rural Communities: Abolition of Commission for Rural Communities. Available at: < http://tinyurl.com/c82tloy>. Accessed: 05 December 2014.

Defra. 2012a. Rural Statement 2012. Available at: <http://tinyurl.com/pybh8lj>. Accessed: 09 December 2014.

Defra. 2013. Rural Communities Policy Unit and Rural Development Programme Evidence Plan. Available at: <http://tinyurl.com/lkydvs8>. Accessed: 06 October 2014.

Defra. 2014. Rural Connections e-Newsletter, February 2014. Available at: <http://tinyurl.com/q822agm>. Accessed: 31 October 2014.

Defra. 2014a. Statistical Digest of Rural England 2014 -December 2014. Department for Environment, Food and Rural Affairs, Nobel House, Smith Square, London.

Derounian, J. 2006. The life and times of the Countryside Agency. A critical commentary. Available at: $<$ http://tinyurl.com/kvf4al5>. Accessed: 04 September 2014.

DETR/MAFF. 2000. Our Countryside the Future. A fair deal for rural England. Cm 4909. ISBN 0-10149092-5. The Stationery Office, Norwich, UK. pp176.

DoE/MAFF. 1995. Rural England - a Nation Committed to a Living Countryside. Cm 3016. HMSO Publications Centre, London. pp146. 
Downing, E., and Kennedy, S. 2014. Food Banks and Food Poverty. House of Commons Standard Note SN06657. House of Commons, UK Parliament. Available at: $<$ http://tinyurl.com/klemzk7>. Accessed: 13 October 2014.

EFRA. 2013. House of Commons Environment, Food and Rural Affairs Committee. Rural Communities, Sixth Report of Session 2013-14. Available at: <http://tinyurl.com/nthxkzf>. Accessed: 30 September 2014.

EFRA. 2013a. House of Commons Environment, Food and Rural Affairs Committee. Rural Communities, Sixth Report of Session 2013-14. Rural Communities: Government Response to the Committee's Sixth Report of Session 2013-14. Available at: <http://tinyurl.com/oqogqfb>. Accessed: 04 May 2015.

Elton, C.J. 2008. The Re-design of Rural Governance: New Institutions for Old? In: Rural Futures: Dreams, Dilemmas and Dangers. (conference paper). The University of Plymouth, UK.

Flinders, M., Dommett, K., and Tonkiss, K. 2014. Bonfires and Barbecues: Coalition Governance and the Politics of Quango Reform. Contemporary British History, 2014, 1-20. Available at: <http://dx.doi.org/10.1080/13619462.2014.882776>. Accessed: 09 December 2014.

FoD. 2002. Landscape Character Assessment. Forest of Dean District Council, Coleford, Gloucestershire, UK. Available at: <http://tinyurl.com/pfgkfvw>. Accessed: 17 October 2014.

Gardiner, H. R. 1943. England Herself-ventures in rural restoration. Faber \& Faber, London.

Grant, W. 2005. Pressure Politics: a Politics of Progressive Consumption? Parliamentary Affairs, 58, (2), 366379. doi: http://dx.doi.org/10.1093/pa/gsi028

Hale, R. 1996. The Effects of Population Sparsity on the Costs of Service Delivery. Sparsely Populated Local Authorities Team, c/o East Dorset District Council, Wimborne, Dorset, UK. pp47.

Hetherington, P. 2013. Who will lead the renaissance for rural communities? The Guardian, 09th April 2013. Available at: <http://tinyurl.com/nbwdewt>. Accessed: 17 September 2014.

Hills, J. 2015. Good Times, Bad Times. The Welfare Myth of Them and Us. ISBN 978-1-44732-003-6. Policy Press, Bristol, UK.

Howard, R. 2015. Warmer Homes - Improving fuel poverty and

energy efficiency policy in the UK. ISBN: 978-1-907689-89-5. Policy Exchange, London, SW1P 3AY.

Hutton, J., Poulter, E., and Robinson, J. 2014. Rural Lifelines Revisited. Involve Yorkshire and Humber, Leeds, UK.

Independent, The. 2011. Coalition MPs condemn abolition of Rural Advocate. 10 July 2011. Available at: <http://tinyurl.com/6j97a91>. Accessed: 24 December 2014.

Independent, The. 2014. Anger as Employment Minister Esther McVey denies food bank use is linked to welfare reforms. 14 May 2014. Available at: < http://tinyurl.com/l3rzdyf >. Accessed: 04 May 2015.

Independent, The. 2015. Prominent fox hunting supporters step up Tory support-and expect repeal of ban in return. 04 May 2015. Available at: http://tinyurl.com/of45g4a. Accessed: 03 April 2015.

Institute for Government. 2012. Bonfire of the Quangos. Available at: <http://tinyurl.com/k2x3xwy>. Accessed: 26 September 2014.

JNCC. 2003. Lord Haskins' Review of Rural Delivery: Possible Implications for the JNCC (JNCC PB 03 P25). Available at: <http://tinyurl.com/q7y46ak $>$. Accessed: 05 September 2014.

Lewis, R., and Talbot-Ponsonby, A. (Eds.). 1987. The People, the Land, and the Church. ISBN 0-902873-083. The Diocese of Hereford, The Palace, Hereford, UK.

Mac. 2014. Pers. Com. 
Marsden, T., Murdoch, J., Lowe, P., Munton, R., and Fklynn, A. 1993. Constructing the Countryside. ISBN 185728-040-7 PB. UCL Press, London.

McLaughlin, B. 1987. Rural Policy into the 1990s - Self Help or

Self Deception. Journal of Rural Studies, 3 (4), 361-364. doi: http://dx.doi.org/10.1016/0743-0167(87)90055-6

Milbourne, P. 2011. Rural Governance. In: Curry, N., and Moseley, M., A Quarter Century of Change in Rural Britain and Europe. Reflections to Mark 25 Years of the Countryside and Community Research Institute. ISBN 1-86174-211-8. The Countryside \& Community Press, CCRI, Gloucester, UK. 49-59.

Moore-Colyer, R.J. 2001. Rolf Gardiner, English patriot and the Council for the Church and Countryside. In: The Agricultural History Review, 49.2, 187-209.

Morris, G. 2012. Leading Communities Community-led Development in England's Small Towns with Particular Reference to an Evaluation of the Market Towns Initiative. In: The Commonwealth Journal of Local Governance, 11, 33-52. Available at: <http://tinyurl.com/nx6dh5q >. Accessed: 03 October 2014.

Morris, G. 2014. What's left, what's been done and what next? England's 2000 Rural White Paper: Town council activities and a survey of town clerks. In: The Commonwealth Journal of Local Governance, 15, 61-85. Available at: <http://tinyurl.com/kavevyf $>$. Accessed: 05 October 2014.

Newby, H., Bell, C., Rose, D, and Saunders, P. 1978. Property, Paternalism and Power - Class and Control in Rural England. ISBN 009133670 8. Hutchinson of London. pp433.

Newby, H. 1988. The Countryside in Question. ISBN 0-09-172950-5. Hurchinson, London.

Parker, G. 1999. Landowner may head rural body Countryside Agency Candidates to Chair Quango Shortlisted. Financial Times, 06 January. ISSN 03071766.

Parker, G. 2011. Rural Governance. In: Curry, N., and Moseley, M., A Quarter Century of Change in Rural Britain and Europe. Reflections to Mark 25 Years of the Countryside and Community Research Institute. ISBN 1-86174-211-8. The Countryside \& Community Press, CCRI, Gloucester, UK. 21-34.

Pierce, R. 2004. Clemenson Revisited - the Rise and Fall of the Great British Landowner. In: Policy Studies, 25 (4) pp283-294. doi: http://dx.doi.org/10.1080/0144287042000288488

Ramblers. 2015. Access to wild, open countryside or the 'right to roam'. Ramblers, Camelford House, 87-90 Albert Embankment, London.

Ranasinghe, J. 2014. DCLG/DEFRA - Research into Drivers of Service Costs in Rural Areas. Rapid Evidence Assessment - Literature Review. November 2014. Available at: <http://tinyurl.com/oqhombz>. Accessed: 06 February 2015. LG Futures Ltd., Marlowe House, Watling Street, Hockliffe, Leighton Buzzard. LU7 9LS. pp28.

RC. 2010. The Rural Challenge. Achieving sustainable rural communities for the 21st century. Available at: $<$ http://tinyurl.com/ns4vzq4>. Accessed: 03 January 2015.

RC. 2014. The Rural Challenge 2015. The Rural Coalition, a united voice for rural England. Available at: $<$ http://tinyurl.com/llwmwc2>. Accessed: 03 January 2015.

RCPU. 2014. Rural Policy Towards 2020 (Presentation). Rural Communities Policy Unit, Defra, London. Available at: <http://tinyurl.com/pkbkfr4>. Accessed: 17 October 2014.

RDC. 1990. The impact of 'Community Post Office' status on rural sub post offices. The Rural Development Commission, Salisbury, UK.

RDC. 1994. Homelessness in rural England - statistical update to 1992/93. The Rural Development Commission, Salisbury, UK.

RDC. 1996. The impact of tourism on rural settlements. The Rural Development Commission, Salisbury, UK.

RDC. 1997. 1997 survey of rural services. The Rural Development Commission, Salisbury, UK. 
RDC. 1997a. Innovation and new technology in small rural firms. The Rural Development Commission, Salisbury, UK.

Rogers, A.W. 1987. Voluntarism, Self-Help and Rural Community Development: Some Current Approaches. In: Journal of Rural Studies. 3, (4), 353-360. doi: http://dx.doi.org/10.1016/0743-0167(87)90054-4

Rogers, A. 1999. The most revolutionary measure. ISBN: 186996471 3. The Rural Development Commission, Salisbury, UK.

Rose, D., Saunders, P., Newby, H., and Bell, C. 1979. The Economic and Political basis of Rural Deprivation: a Case Study. In: Shaw, J.M., Rural Deprivation and Planning. ISBN 0860940 195. GeoAbstracts, University of East Anglia, Norwich, UK.

S\&D. 1955. Somerset and Dorset Joint Rural Industries Sub-Committee. In: Somerset and Dorset Joint Rural Industries Committee minute book. Held by the writer.

Shucksmith, M., Roberts, D., Scott, D., Chapman, P., and Conway, E. 1996. Disadvantage in rural areas. ISBN 186996455 1. The Rural Development Commission, Salisbury, Wilts. UK.

Shucksmith, M. 2013. Environment, Food and Rural Affairs Committee - Minutes of Evidence, HC 602. UK Parliament. Available at: <http://tinyurl.com/o6okjxd>. Accessed: 28 August 2014.

Sissons, M. 2001. A Countryside for all. In: Sissons, M., A Countryside for all. ISBN 0099-42889 X. Vintage, London. pp169-182.

Skidelsky, R. 2001. Foreword. In: Sissons, M., A Countryside for all. ISBN 0099-42889 X. Vintage, London. pp3-12.

Smith, D. 1992. Village Shops and Post Offices. A Report to the Rural Development Commission. Wessex Rural Consultants, Halstock, Yeovil, Somerset, UK. pp122.

Social Mobility and Child Poverty Commission. 2014. State of the Nation 2014: Social Mobility and Child Poverty in Great Britain. ISBN 9781474111201 . Available at: <http://tinyurl.com/oqcpbqu $>$. Accessed: 22 October 2014.

Sturzakar, J., and Shucksmith, M. 2011. Planning for housing in rural England, Discursive power and spatial exclusion. In: The Town Planning Review. 82, (2) pp169-193. doi: http://dx.doi.org/10.3828/tpr.2011.11

TFS. 1906. Socialism and Labor [sic] Policy. Fabian Tract No. 127. The Fabian Society, London.

Trussell Trust. 2014. Latest Foodbank Figures top 900,000. Available at: <http://tinyurl.com/nddaofq $>$. Accessed: 12 December 2014.

Trussell Trust. 2015. 1,084,604 people were given 3 days' emergency food and support in 2014-2015. Available at: <http://www.trusselltrust.org/stats\#our-stats-explained. Accessed: 04 May 2015.

UK Government. 2014. Government unveils $£ 2$ billion in cumulative savings as public bodies are cut by a third. Available at: <http://tinyurl.com/k4hdh6p >. Accessed: 09 December 2014.

Wiredgov. 2008. Rural Advocate reports to Prime Minister on realities of rural England. Available at: <http://tinyurl.com/loo73ad>. Accessed: 24 December 2014.

Woods, M. 1997. Discourses of power and rurality. Local politics in Somerset in the $20^{\text {th }}$ century. In: Political Geography, 16, (6), 453-478. doi: http://dx.doi.org/10.1016/S0962-6298(96)00021-2

Woods, M. 2005. Rural Geography. Processes, Responses and Experiences in Rural Restructuring. ISBN 07619-4761-2. Sage Publications, London. 